\title{
FORMONONETIN ASSOCIATED WITH PHOSPHORUS INFLUENCES SOYBEAN SYMBIOSIS WITH MYCORRHIZAL FUNGI AND Bradyrhizobium
}

\author{
FORMONONETINA ASSOCIADA COM FÓSFORO INFLUENCIA A SIMBIOSE DE \\ SOJA COM FUNGOS MICORRÍZICOS E Bradyrhizobium
}

\author{
Paula Rose de Almeida RIBEIRO' ${ }^{1}$; Jessé Valentim dos SANTOS ${ }^{1}$; \\ Teotonio Soares de CARVALHO ${ }^{1}$; Jacqueline Savana da SILVA ${ }^{1}$; \\ Pedro Milanez de REZENDE ${ }^{2}$; Fatima Maria de Souza MOREIRA ${ }^{1,3}$
}

1. Sector of Biology, Microbiology and Biological Processes, Department of Soil Science, Federal University of Lavras, Lavras, Minas Gerais, Brazil; 2. Professor of Department of Agriculture, Federal University of Lavras, Lavras, Minas Gerais, Brazil; 3. Professor of Department of Soil Science, Federal University of Lavras, Lavras, Minas Gerais, Brazil. Productivity research scholarship (CNPq). fmoreira@dcs.ufla.br

\begin{abstract}
Arbuscular mycorrhizal fungi play an important role on nutrient supply to plants, specially P. However, the availability of inoculants for large-scale usage in agriculture is still limited because these organisms are obligatory symbionts. The use of symbiosis stimulants such as flavonoids can be an alternative to improve the beneficial effects of mycorrhiza for plant nutrition. The aim of this study was to evaluate the effect of the isoflavonoid biostimulant formononetin (7-hydroxy, 4'-methoxy isoflavone) in combination with three levels of phosphorus fertilization on mycorrhizal colonization, nodulation, and productivity of soybean, under field conditions. A 3 x 4 factorial scheme (levels of P: 0, 60 and $120 \mathrm{~kg} \mathrm{ha}^{-1} \mathrm{P}_{2} \mathrm{O}_{5}$ and doses of formononetin: 0, 25, 50 and $100 \mathrm{~g} \mathrm{ha}^{-1}$ ) was used with five replicates. The following parameters were quantified at full bloom: plant height, shoot dry weight, nodule number, nodule dry weight, mycorrhizal colonization, and shoot $\mathrm{N}$ and $\mathrm{P}$ concentrations. Productivity was also evaluated at the end of the crop cycle. Formononetin stimulated mycorrhizal colonization at lower levels of $\mathrm{P}\left(0\right.$ and $\left.60 \mathrm{~kg} \mathrm{ha}^{-1}\right)$, with colonization increasing from 56 to $64 \%$. When applied with $60 \mathrm{~kg} \mathrm{ha}^{-1} \mathrm{P}_{2} \mathrm{O}_{5}$, formononetin increased soybean productivity to values similar to those observed when $120 \mathrm{~kg} \mathrm{ha}^{-1}$ de $\mathrm{P}_{2} \mathrm{O}_{5}$, was applied. At doses above $50 \mathrm{~g} \mathrm{ha}^{-1}$, formononetin applied to the seeds can reduce the need of $\mathrm{P}$ fertilization by $50 \%$.
\end{abstract}

KEYWORDS: Arbuscular mycorrhiza. Glycine max. Phosphorus fertilization. Isoflavonoid. $\mathrm{N}_{2}$-fixing bacteria.

\section{INTRODUCTION}

Soybean (Glycine max (L.) Merrill) is an important source of protein in the human and animal food chains. This crop has high economic and social importance in Brazil, the greatest soybean producer worldwide. In Brazil, soybean is predominantly cropped in soils characterized by low availability of $\mathrm{N}$ and $\mathrm{P}$, making these nutrients the main limiting factors to the growth and agricultural productivity of soybean (CORDEIRO et al., 2015; YAMADA; ABDALLA, 2004). Because soybean can form symbiosis with $\mathrm{N}_{2}$-fixing bacteria belonging to the genus Bradyrhizobium, the plant demand for $\mathrm{N}$ may be completely supplied by biological nitrogen fixation (MOREIRA; SIQUEIRA, 2006). In addition, the need for $\mathrm{P}$ fertilization can be reduced by arbuscular mycorrhizal fungi (AMF), which improve $\mathrm{P}$ uptake by their host plants due to the establishment of a hyphal network that increases the volume of soil exploited by the root (PARNISKE, 2008; STÜRMER; SIQUEIRA, 2013).

Soybean plants form symbiotic associations with both $\mathrm{N}_{2}$-fixing bacteria and AMF, with the interaction among the three organisms resulting in a tripartite symbiosis (ANTUNES et al., 2006). Synergetic effects of this tripartite symbiosis have been observed, mainly in conditions of low levels of $\mathrm{P}$ and N (MOREIRA et al., 2010; WANG et al., 2011). Despite the known beneficial effects of these fungi, their use in agriculture is limited because they are obligate biotrophs and their inoculum mass production is economically unviable. However, the discovery of the effects of the isoflavone formononetin stimulant on mycorrhizal colonization (NAIR et al., 1991; SIQUEIRA et al., 1991a) has opened new possibilities for the management of native AMF in agriculture. Formononetin affects the colonization and sporulation of AMF in Brachiaria (NOVAIS; SIQUEIRA, 2009) and stimulates colonization in maize (SILVA-JÚNIOR; SIQUEIRA, 1997; 1998), under controlled conditions. In soybean Cordeiro et al. (2015) reported that formononetin increased mycorrhizal colonization, nodulation, plant growth, and productivity in both greenhouse and field conditions, attenuating the negative effects of fungicides.

The effectiveness of the mycorrhizal symbiosis for plant growth is dependent on 
edaphoclimatic and biological conditions in the soil (SMITH; READ, 1997). Therefore, the results of previous works on formononetin, which were predominantly carried out in controlled conditions, cannot be directly extended to field conditions. So, field experiments are essential to confirm the effect of formononetin on tripartite symbiosis and on parameters of phytotechnic interest, such as productivity. This is especially important because an increase in $\mathrm{P}$ uptake efficiency, associated with satisfactory productivity, can considerably decrease the need for P fertilization.

This study was done to evaluate the effect of the isoflavone formononetin associated with different levels of phosphorus fertilization on mycorrhizal colonization, nodulation, and productivity of soybean inoculated with commercial Bradyrhizobium strains under field conditions.

\section{MATERIAL AND METHODS}

\section{Site characterization}

Two experiments were conducted in Ijaci municipality, Minas Gerais, Brazil. Experiment 1: $21^{\circ} 12^{\prime}, 17^{\prime \prime} \mathrm{S}, 44^{\circ} 58^{\prime} 49^{\prime}$ ' $\mathrm{W}$ and $957 \mathrm{~m}$ altitude, in $2010 / 11$ and experiment 2: $21^{\circ} 12^{\prime} 10^{\prime}$ ' $\mathrm{S}$, $44^{\circ} 58^{\prime} 50^{\prime \prime} \mathrm{W}$ and $957 \mathrm{~m}$ altitude) in 2012/13. According to the Köppen classification the region's climate is mesothermal, with dry winters (Cwb) (KÖPPEN, 1936), a $19.3{ }^{\circ} \mathrm{C}$ annual average temperature, and a $1.411 \mathrm{~mm}$ annual average rainfall. Average temperature and accumulated rainfall during the experimental period was $22{ }^{\circ} \mathrm{C}$ for the two agricultural years and $1.425 \mathrm{~mm}$ in $2010 / 11$ and $1.080 \mathrm{~mm}$ in $2012 / 13$ (Fig. 1). These climatological data were provided by the Principal Climatological Station of Lavras, Minas Gerais, Brazil (agreement UFLA/INMET).

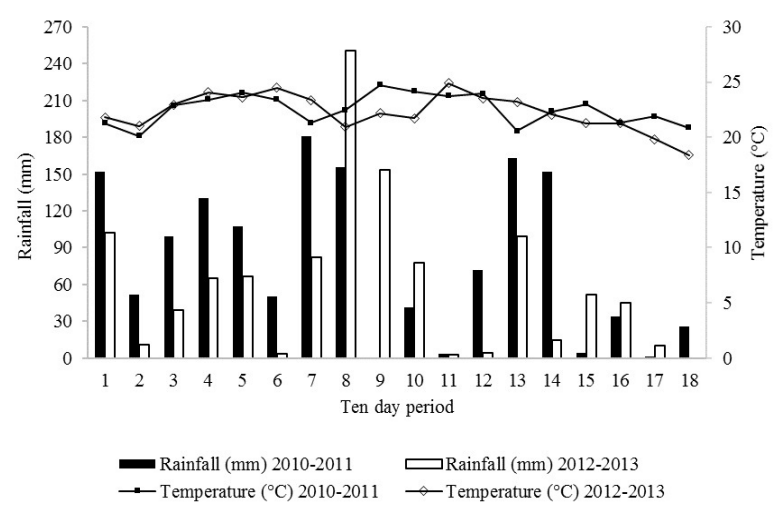

Figure 1. Average temperature (lines) and accumulated rainfall (bars) per ten days period from 11/01/2010 to $04 / 29 / 2011$ and from $11 / 01 / 2012$ to $04 / 30 / 2013$. The periods $9-11$ in 2010/11 and $11-12$ in 2012/13 correspond to the early stages of the reproductive phase (R1-R6).

The experimental areas were fallow land until 2009 and were then cultivated with maize until April 2010. The areas were again left as fallow, with growth of spontaneous vegetation, predominantly Brachiaria, until prepared for the experiments. The soil at the experimental sites is a dystrophic Yellow Red Latosol (Oxisol), with the following chemical and physical characteristics: experiment $1-\mathrm{pH}$ $\left(\mathrm{H}_{2} \mathrm{O}\right)=6.5, \mathrm{H}+\mathrm{Al}=2.3 \mathrm{cmol}_{\mathrm{c}} \mathrm{dm}^{-3}, \mathrm{Al}=0.01$ $\mathrm{cmol}_{\mathrm{c}} \mathrm{dm}^{-3}, \mathrm{Ca}=3.8 \mathrm{cmol}_{\mathrm{c}} \mathrm{dm}^{-3}, \mathrm{Mg}=1.5 \mathrm{cmol}_{\mathrm{c}}$ $\mathrm{dm}^{-3}$, cation exchange capacity $(\mathrm{CEC})=7.9 \mathrm{cmol}_{\mathrm{c}}$ $\mathrm{dm}^{-3}, \mathrm{~K}=101.0 \mathrm{mg} \mathrm{dm}^{-3}, \mathrm{P}=10.3 \mathrm{mg} \mathrm{dm}^{-3}$, clay $=$ $570 \mathrm{~g} \mathrm{~kg}^{-1}$, silt $=80 \mathrm{~g} \mathrm{~kg}^{-1}$, and sand $=350 \mathrm{~g} \mathrm{~kg}^{-1}$; experiment 2 - water $\mathrm{pH}=5.9, \mathrm{H}+\mathrm{Al}=2.9 \mathrm{cmol}_{\mathrm{c}}$ $\mathrm{dm}^{-3}, \mathrm{Al}=0.0 \mathrm{cmol}_{\mathrm{c}} \mathrm{dm}^{-3}, \mathrm{Ca}=4.7 \mathrm{cmol}_{\mathrm{c}} \mathrm{dm}^{-3}, \mathrm{Mg}$ $=1.3 \mathrm{cmol}_{\mathrm{c}} \mathrm{dm}^{-3}, \mathrm{CEC}=9.2 \mathrm{cmol}_{\mathrm{c}} \mathrm{dm}^{-3}, \mathrm{~K}=118.0$ $\mathrm{mg} \mathrm{dm}^{-3}, \mathrm{P}=7.2 \mathrm{mg} \mathrm{dm}^{-3}$, clay $=570 \mathrm{~g} \mathrm{~kg}^{-1}$, silt $=$ $80 \mathrm{~g} \mathrm{~kg}^{-1}$, and sand $=350 \mathrm{~g} \mathrm{~kg}^{-1}$.

\section{Density of native nodulating nitrogen-fixing bacteria in Leguminosae (NNFBL) and AMF spores}

The most probable number of cells of NNFBL native to the cultivated area was estimated in the first year (2010/11). Prior to soil tillage, three composite samples obtained from five subsamples were collected from the $0-20 \mathrm{~cm}$ soil layer along the experimental area. The samples were placed in sterile plastic bags and stored at $4{ }^{\circ} \mathrm{C}$ until analysis.

The experiment was conducted in a greenhouse, with sterilized long neck glass bottles $(500 \mathrm{~mL})$ containing Hoagland and Arnon (1950) nutrient solution with $5.25 \mathrm{mg} \mathrm{L}^{-1} \mathrm{~N}\left(\mathrm{NH}_{4} \mathrm{NO}_{3}\right.$ and $\mathrm{KNO}_{3}$ ). Filter paper was used as support for root development of the soybean plants (FLORENTINO; MOREIRA, 2009). The soybean cultivar FAVORITA RR was used as a trap plant. Soybean seeds were previously surface sterilized with $70 \%$ 
ethanol for 30 seconds and 2-3\% sodium hypochlorite for two minutes and then washed six times with sterile distilled water. The seeds were pre-germinated in Petri dishes containing filter paper and moistened sterile cotton at $28^{\circ} \mathrm{C}$ for two days.

Serial dilutions $\left(10^{-1}\right.$ to $\left.10^{-7}\right)$ of each of the three soil samples were performed. The pregerminated seeds were inoculated with $1 \mathrm{~mL}$ of each of the serial dilutions, with three replicates per dilution. Bradyrhizobium elkanii Br 29 (SEMIA 5019), which is approved as an inoculant for soybean by the Brazilian Ministry of Agriculture, Livestock and Food Supply (Brazil) was used as a positive control. Two uninoculated negative controls were used for the detection of any possible contamination: one with the addition of $52.5 \mathrm{mg} \mathrm{L}^{-1}$ mineral N; and another with $5.25 \mathrm{mg} \mathrm{L}^{-1}$ mineral $\mathrm{N}$, a low $\mathrm{N}$ supply.

Nodulation was quantified 30 days following inoculation. Most probable number was determined by verifying presence or absence of nodules for each dilution and using the "Most Probable Number Estimate" software (WOOMER et al., 1988).

Native AMF spore density was quantified according to Gerdemann and Nicolson (1963) using $50 \mathrm{~g}$ of soil from the same soil samples used for the quantification of native NNFBL. These quantifications were performed only during the first year of cultivation.

\section{Experimental design}

A randomized block experimental design was used with a $3 \times 4$ factorial scheme, with the first factor being three levels of $\mathrm{P}$ addition: 0,60 and 120 $\mathrm{kg} \mathrm{ha}^{-1} \mathrm{P}_{2} \mathrm{O}_{5}$. For the area of the first experiment (2010/11), based on the P concentration originally found in the soil (see site characterization above), these three levels of $\mathrm{P}$ addition correspond to 0 , $75 \%$, and $150 \%$ of the $\mathrm{P}$ fertilization recommended by Novais et al. (1999) for soybean; for the area of the second experiment (2012/13), those three levels of $\mathrm{P}_{2} \mathrm{O}_{5}$ addition correspond to 0,50 , and $100 \%$ of the recommend $\mathrm{P}$ fertilization. The second factor of the factorial scheme consisted of four addition doses of the biostimulant formononetin, 7-hydroxy, 4'methoxy isoflavone, $\left(0,25,50\right.$ and $\left.100 \mathrm{~g} \mathrm{ha}^{-1}\right)$, as the commercial product PHC-506, according to the manufacturers' recommendations (Plant Health Care). The soybean cultivar FAVORITA RR, which is appropriate for the region, was used in both experiments. Six rows, $6 \mathrm{~m}$ long each, were set at the experimental plots, with a $0.45 \mathrm{~m}$ spacing. Five replicates were used for experiment 1 (2010/11), and four replicates were used for experiment 2 $(2012 / 13)$. The four central rows were used for data collection in each plot, with the border of the plots $(0.5 \mathrm{~m})$ being discarded.

Soil preparation consisted of one plowing and one harrowing, followed by the opening of plantation furrows. Fertilization was performed manually prior to sowing. The different levels of $\mathrm{P}_{2} \mathrm{O}_{5}$ for each treatment were applied as a single superphosphate together with $40 \mathrm{~kg} \mathrm{~K}_{2} \mathrm{O} \mathrm{ha}^{-1}$, as $\mathrm{KCl}$, to the plantation furrows. Soybean seeds were previously inoculated with a commercial peat-based inoculant. Experiment 1: Biomax premium peat (100 g inoculant, $5 \times 10^{9}$ cells g ${ }^{-1}$, per $50 \mathrm{~kg}$ seeds,) containing Bradyrhizobium japonicum (SEMIA 5079 and 5080). Experiment 2: Adhere $60^{\mathrm{R}}(60 \mathrm{~g}$ inoculant per $50 \mathrm{~kg}$ seeds) containing Bradyrhizobium elkanii (SEMIA 587 and 5019). After that, the seeds in both experiments received different doses of formononetin. Sowing was performed in Dec. 2010 and 2012, and harvests occurred in Apr. 2011 and 2013, respectively. Crop handling (manual weeding) was performed during the course of crop development.

\section{Parameters quantified at flowering ( $R 2$ stage) in the field Mycorrhizal colonization}

Approximately $1 \mathrm{~g}$ of fine roots was collected from four plants per experimental plot. The roots were washed, cleared with $10 \% \mathrm{KOH}$, washed again in running water and placed in $1 \%$ $\mathrm{HCl}$ for five minutes. The roots were then stained with Trypan Blue (KOSKE; GEMMA, 1989). Stained roots were placed in gridded Petri dishes, and percentage colonization was quantified according to Giovannetti and Mosse (1980).

\section{Number of nodules and nodule dry weight}

Plant nodulation was quantified by removing the nodules from the root system of five plants per plot. Roots were placed on a sieve, and the nodules were separated, counted, and dried in an oven at $60^{\circ} \mathrm{C}$ to obtain the nodules dry weight.

\section{Plant height, shoot dry weight, concentrations and total contents of nutrients}

Five plants per plot were collected at the R2 stage for the quantification of plant height, shoot dry weight, concentrations and total contents of nutrients. The collected plants were placed in paper bags and maintained in a forced air circulation oven at $60{ }^{\circ} \mathrm{C}$ until constant weight was reached, and the shoot dry weight was measured using a digital balance. The dry shoots were homogenized and used 
for the determination of shoot nutrient concentrations. Phosphorus concentrations were measured using colorimetry following nitricperchloric digestion of the samples. Calcium, $\mathrm{Mg}$, $\mathrm{Zn}, \mathrm{Cu}$ and $\mathrm{Fe}$ concentrations were determined by atomic absorption spectroscopy, and $\mathrm{N}$ concentrations were determined using the microKjeldahl method (MALAVOLTA et al., 1997). Shoot total nutrient contents were calculated by multiplying the shoot dry weight by the nutrient concentrations. For the second cultivation year, only the $\mathrm{N}$ and $\mathrm{P}$ concentrations were quantified, according to the methodology described above.

\section{Productivity}

Productivity was quantified at the end of the crop cycle. Plants of the two central rows of each plot were collected, excluding $0.5 \mathrm{~m}$ from the transect extremities, with a total $4.5 \mathrm{~m}^{2}$ useful area. Productivity was corrected for $13 \%$ humidity.

\section{Statistical analysis}

Analysis of variance (ANOVA by $\mathrm{F}$ test) followed by a Scott-Knot test at $5 \%$ probability and regression analysis were performed using the Sisvar software, version 4.0 (FERREIRA, 2011).

\section{RESULTS AND DISCUSSION}

\section{Density of NNFBL and AMF spores}

The average density of native NNFBL measured in soybean trap plants was $540 \mathrm{CFU} \mathrm{g}^{-1}$ soil. AMF spore density was 3.5 spores per $\mathrm{g}^{-1}$ soil. The number of AMF spores in soil depends on AMF species, climate, soil characteristics and seasonality (SMITH; READ, 1997). This density influences the stimulatory effect of formononetin on plant growth, with spore densities ranging from 2 to 4 spores per $\mathrm{g}^{-1}$ resulting in highest responses of cover plants to formononetin application (SIQUEIRA et al., 1991a). It should be noted that in addition to spores, other structures, such as hyphae fragments, mycelium and colonized roots, can be used for propagation. Because spontaneous vegetation grew in the area prior to soybean planting, part of these structures may have remained active in the soil even following its preparation. This is relevant because the stimulation of mycorrhizal colonization by formononetin varies with soil infectivity (SIQUEIRA et al., 1991a; SILVA-JÚNIOR; SIQUEIRA, 1997).

\section{Mycorrhizal colonization}

Mycorrhizal colonization varied with the addition of formononetin from approximately 56\% up to $66 \%$ with different levels of $\mathrm{P}$ addition during the two years of study. In 2010/11, increasing doses of formononetin raised mycorrhizal colonization from approximately $57 \%$ to $64 \%$ when 0 or $60 \mathrm{~kg}$ ha $^{-1} \mathrm{P}_{2} \mathrm{O}_{5}$ doses were used (Figure 2A). A similar effect was observed in 2012/13 with $60 \mathrm{~kg} \mathrm{ha}^{-1}$ $\mathrm{P}_{2} \mathrm{O}_{5}$, with mycorrhizal colonization increasing from approximately $55 \%$ to $61 \%$ (Figure $2 \mathrm{~B}$ ). However, in 2012/13, with no $\mathrm{P}_{2} \mathrm{O}_{5}$ addition, formononetin did not affect mycorrhizal colonization. In 2010/11, when $120 \mathrm{~kg} \mathrm{ha}^{-1} \mathrm{P}_{2} \mathrm{O}_{5}$ was added to the soil, formononetin did not affect mycorrhizal colonization. In fact, the addition of high levels of $\mathrm{P}$ tends to inhibit or limit mycorrhizal colonization, and in conditions of low $\mathrm{P}$ availability, mycorrhization tends to be higher compared with plants receiving the maximum supply of $\mathrm{P}$ (MOREIRA et al., 2010).

Several studies under controlled conditions, have shown the benefits of the use of formononetin on mycorrhization (NOVAIS; SIQUEIRA, 2009; SIQUEIRA et al., 1991a, b; SILVA-JÚNIOR; SIQUEIRA, 1997). For example, in maize and soybean, formononetin increased percentage of colonization and densities of arbuscules and vesicles (SILVA-JÚNIOR; SIQUEIRA, 1997). An 89\% increase in sporulation and a $60 \%$ increase in mycorrhizal colonization were reported for Brachiaria (NOVAIS; SIQUEIRA, 2009). Under low $\mathrm{P}$ availability, formononetin stimulates root colonization by AMF (DAVIES et al., 2005a, b). More recently, increases in the mycorrhizal colonization and soybean grain yield were observed by Cordeiro et al. (2015) at Goiás state under field conditions. These authors reported that the positive effects of formononetin on mycorrhization in the flowering/filling contributed to plant nutrition.

Evidences that formononetin can be metabolized by the soil microbial community were reported in Ozan et al. (1997). They observed that two and three weeks after adding formononetin to nonsterile soil, $40 \%$ and $95 \%$ of the isoflavone could not be recovered, respectively. Furthermore, the added formononetin stimulated the growth of some soil microorganisms (e.g. actinobacteria and bacteria). In contrast, the concentration of formononetin in the sterile soil did not vary over a period of 15 days after its application. Therefore, the ability of the soil microrganisms to degradate formononetin is possibly one of the factors that control the outcome of formononetin application on plant growth. 

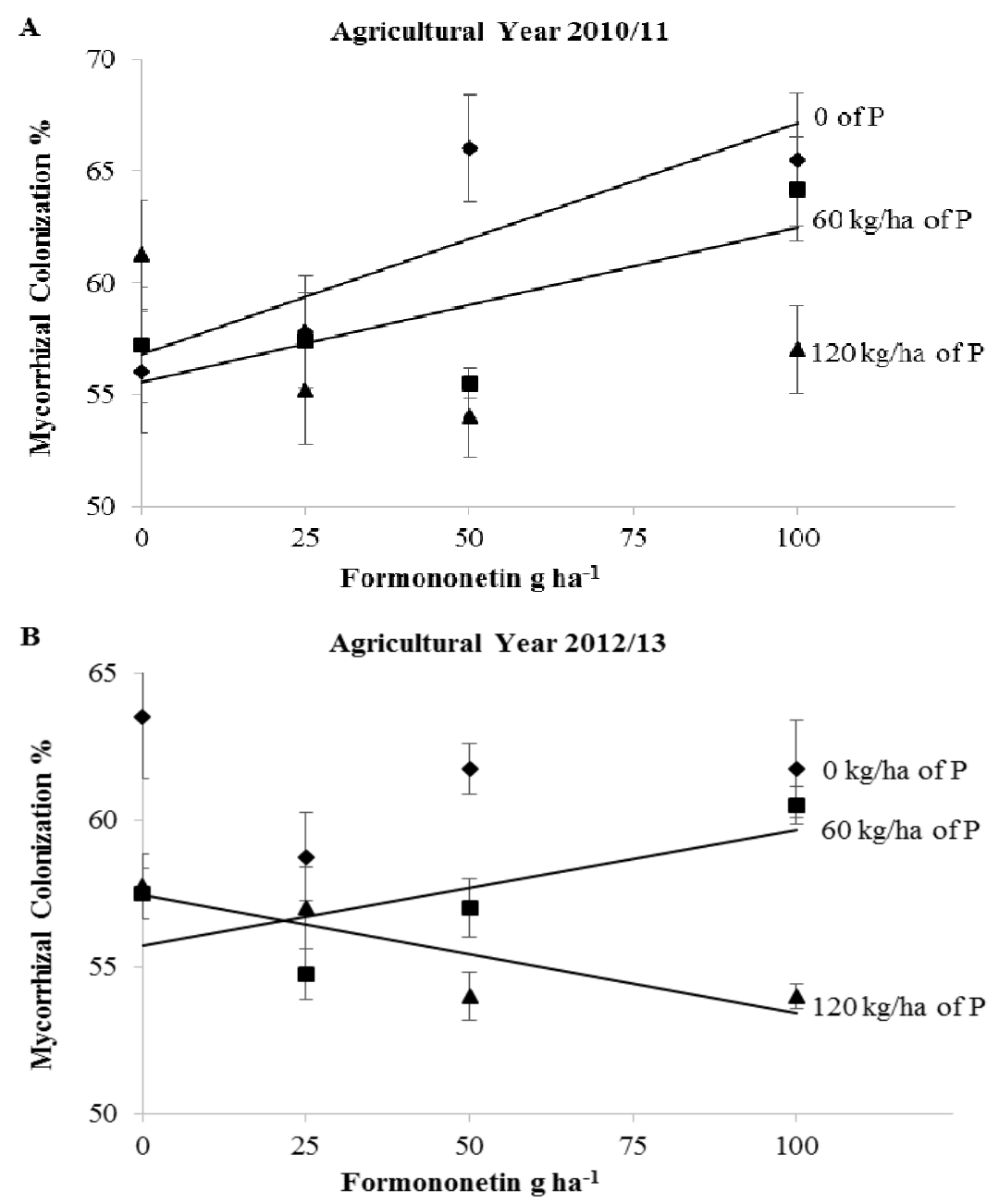

Figure 2. Mycorrhizal colonization of soybean after treatment with different doses of formononetin and different levels of $P$ for the agricultural years (A) 2010/11 and (B) 2012/13. *Significant at $P<0.05$ and ns not significant according to the $\mathrm{F}$ test. (A) $\mathrm{y}_{0}=0.103 \mathrm{x}+56.82 \mathrm{R}^{2}=0.70^{*} ; \mathrm{y}_{60}=0.0694 \mathrm{x}+$ $55.54 \mathrm{R}^{2}=0.60^{*} ; \mathrm{y}_{120}=-0.0313 \mathrm{x}+58.23 \mathrm{R}^{2}=0.18^{\mathrm{ns}}$ and $(\mathrm{B}) \mathrm{y}_{0}=-0.0037 \mathrm{x}+61.6 \mathrm{R}^{2}=0.01^{\mathrm{ns}} ; \mathrm{y}_{60}=$ $0.0397 x+55.7 R^{2}=0.51^{*} ; y_{120}=-0.0403 x+57.45 R^{2}=0.76^{*}$.

Plant height, shoot dry weight, number of nodules and nodule dry weight

In general, the application of formononetin associated with the addition of $\mathrm{P}_{2} \mathrm{O}_{5}$ at different levels did not affect the number of nodules or nodule dry weight (Table 1). This indicates that formononetin does not have a negative effect on soybean nodulation, which is in accordance with previous reports (SILVA-JÚNIOR; SIQUEIRA, 1997; SILVA-JÚNIOR; SIQUEIRA, 1998). In a pot experiment using soil, formononetin stimulated mycorrhizal development but had a reduced effect on soybean dry weight (SILVA-JÚNIOR; SIQUEIRA, 1997). In white clover, formononetin was observed to increase nodulation in the presence of AMF, which was thought to result from higher mycorrhizal colonization and plant growth (SIQUEIRA et al., 1991a)

Very little is known about the relationship of formononetin and the nodulation of soybean. The flavones genistein, daidzein and coumestrol appear to have an important role in the early signaling events of the establishment of symbioses with both rhizobia and AMF. However, some flavones, such as glycitein and formononetin, do not appear to act as signaling molecules in the establishment of the tripartite symbiosis in soybean (ANTUNES et al., 2006). Formononetin was not detected in root and seed of soybean in the study of Antunes et al. (2006). However, the formononetin significantly decreased expression of nodABC-lacZ genes, required for nodulation, in $B$. japonicum (KOSSLAK et al., 1987). 
Table 1. Average values of plant height, shoot dry weight, nodules number and dry weight of soybean cv. Favorita RR at flowering in two crop seasons with different phosphorus levels and formononetin doses.

\begin{tabular}{|c|c|c|c|c|c|c|c|c|}
\hline \multirow{3}{*}{$\begin{array}{c}\text { Phosphorus } \\
\text { Levels } \\
\left(\mathrm{kg} \mathrm{ha}^{-1}\right)\end{array}$} & \multicolumn{8}{|c|}{ Formononetin doses $\mathrm{g} \mathrm{ha}^{-1}$} \\
\hline & \multicolumn{3}{|c|}{$2010 / 11$} & \multicolumn{5}{|c|}{$2012 / 13$} \\
\hline & 0 & 25 & 50 & 100 & 0 & 25 & 50 & 100 \\
\hline \multicolumn{9}{|l|}{ Plant height $(\mathrm{cm})$} \\
\hline 0 & $39.22 \mathrm{aA}$ & $46.28 \mathrm{aA}$ & $43.18 \mathrm{aA}$ & $46.52 \mathrm{aA}$ & $37.68 \mathrm{cB}$ & $37.80 \mathrm{cB}$ & $39.65 \mathrm{cA}$ & $41.58 \mathrm{cA}$ \\
\hline 60 & $45.96 \mathrm{aA}$ & $43.36 \mathrm{aA}$ & $43.56 \mathrm{aA}$ & $48.58 \mathrm{aA}$ & $42.83 \mathrm{bB}$ & $41.85 \mathrm{bB}$ & $43.63 \mathrm{bB}$ & $46.60 \mathrm{bA}$ \\
\hline 120 & $47.72 \mathrm{aA}$ & $46.16 \mathrm{aA}$ & $42.50 \mathrm{aA}$ & $46.82 \mathrm{aA}$ & $46.88 \mathrm{aB}$ & $48.75 \mathrm{aB}$ & $51.05 \mathrm{aA}$ & $51.23 \mathrm{aA}$ \\
\hline \multicolumn{9}{|c|}{ Shoot dry weight (g) } \\
\hline 0 & $9.09 \mathrm{aA}$ & $11.42 \mathrm{aA}$ & $8.82 \mathrm{aA}$ & $8.97 \mathrm{aA}$ & $9.46 \mathrm{bB}$ & $9.27 \mathrm{cB}$ & $10.53 \mathrm{bA}$ & $11.14 \mathrm{bA}$ \\
\hline 60 & $10.69 \mathrm{aA}$ & $9.81 \mathrm{aA}$ & $12.15 \mathrm{aA}$ & $11.61 \mathrm{aA}$ & $10.57 \mathrm{bB}$ & $10.92 \mathrm{bB}$ & $11.64 \mathrm{aA}$ & $12.36 \mathrm{aA}$ \\
\hline 120 & $10.57 \mathrm{aA}$ & $11.66 \mathrm{aA}$ & $10.78 \mathrm{aA}$ & $11.62 \mathrm{aA}$ & $13.32 \mathrm{aA}$ & $14.96 \mathrm{aA}$ & $12.53 \mathrm{aA}$ & $13.14 \mathrm{aA}$ \\
\hline \multicolumn{9}{|l|}{ Number of nodules } \\
\hline 0 & $102 \mathrm{aA}$ & $88 \mathrm{aA}$ & $88 \mathrm{bA}$ & $94 \mathrm{aA}$ & $97 \mathrm{aA}$ & $108 \mathrm{aA}$ & $106 \mathrm{aA}$ & $86 \mathrm{bA}$ \\
\hline 60 & $121 \mathrm{aA}$ & $92 \mathrm{aA}$ & $95 \mathrm{bA}$ & $105 \mathrm{aA}$ & $119 \mathrm{aA}$ & $85 \mathrm{aA}$ & $95 \mathrm{aA}$ & $94 \mathrm{bA}$ \\
\hline 120 & $91 \mathrm{aA}$ & $113 \mathrm{aA}$ & $124 \mathrm{aA}$ & $120 \mathrm{aA}$ & $101 \mathrm{aA}$ & $100 \mathrm{aA}$ & $96 \mathrm{aA}$ & $126 \mathrm{aA}$ \\
\hline \multicolumn{9}{|c|}{ Nodule dry weight (g) } \\
\hline 0 & $1.53 \mathrm{aA}$ & $1.62 \mathrm{bA}$ & $1.39 \mathrm{bA}$ & $1.40 \mathrm{aA}$ & $1.82 \mathrm{aA}$ & $1.56 \mathrm{bA}$ & $1.67 \mathrm{aA}$ & $1.54 \mathrm{bA}$ \\
\hline 60 & $2.13 \mathrm{aA}$ & $2.31 \mathrm{aA}$ & $1.68 \mathrm{aA}$ & $1.63 \mathrm{aA}$ & $1.98 \mathrm{aA}$ & $1.57 \mathrm{bA}$ & $1.81 \mathrm{aA}$ & $1.91 \mathrm{aA}$ \\
\hline 120 & $1.83 \mathrm{aA}$ & $1.83 \mathrm{bA}$ & $1.90 \mathrm{aA}$ & $2.00 \mathrm{aA}$ & $1.83 \mathrm{aA}$ & $1.94 \mathrm{aA}$ & $1.99 \mathrm{aA}$ & $2.11 \mathrm{aA}$ \\
\hline
\end{tabular}

lower case letters indicate comparisons among different $\mathrm{P}_{2} \mathrm{O}_{5}$ addition levels within the same agricultural year. 
Plant growth, measured by plant height and shoot dry weight, was not affected by formononetin application in 2010/11, but stimulatory effects of formononetin on plant growth were observed in 2012/13, especially for doses of formononetin above $50 \mathrm{~g} \mathrm{ha}^{-1}$.

\section{Concentrations and total contents of $\mathbf{N}$ and $P$}

Shoot $\mathrm{N}$ and $\mathrm{P}$ concentrations were not influenced by the application of formononetin or fertilization with $\mathrm{P}_{2} \mathrm{O}_{5}$ during the two years of cultivation (Table 2). The average $\mathrm{N}$ and $\mathrm{P}$ concentrations were 21.23 and $1.17 \mathrm{~g} \mathrm{~kg}^{-1}$ in 2010/11 and 23.38 and $1.20 \mathrm{~g} \mathrm{~kg}^{-1}$ in 2012/13, respectively. These values were below the levels considered adequate for soybean, which are 55-58 g $\mathrm{kg}^{-1}$ for $\mathrm{N}$ and $4-5 \mathrm{~g} \mathrm{~kg}^{-1}$ for P (MALAVOLTA, 2006). Leaf concentrations of $\mathrm{Ca}, \mathrm{Mg}, \mathrm{Zn}, \mathrm{Cu}, \mathrm{Fe}$ and $\mathrm{Mn}$, which were quantified only in 2010/11, were not influenced by the application of formononetin and $\mathrm{P}_{2} \mathrm{O}_{5}$ (results not shown).

On the other hand, the use of different doses of formononetin and different levels of $\mathrm{P}_{2} \mathrm{O}_{5}$ had effect $(P<0.05)$ on total content of $\mathrm{N}$ and $\mathrm{P}$ shoot contents only in 2012/13 (Table 2). Increasing doses of formononetin together with the addition of $60 \mathrm{~kg}$ $\mathrm{P}_{2} \mathrm{O}_{5}$ increased the uptake of $\mathrm{N}$ and $\mathrm{P}$.

\section{Productivity}

Average soybean productivity varied from approximately $2010-2674 \mathrm{~kg} \mathrm{ha}^{-1}$ in $2010 / 11$ and from 1969-2604 kg ha ${ }^{-1}$ in 2012/13 (Fig. 3A and 3B). The productivity averages for the two studied years were below those reported (2899 and $2996 \mathrm{~kg}$ $\mathrm{ha}^{-1}$, respectively) for the region during the same period (CONAB, 2013), probably because of the low precipitation at the early stages of the reproductive phase, R1-R6. However, total precipitation and mean temperature were within the range considered appropriate for this culture (FARIAS et al., 2007).

With no addition of $\mathrm{P}_{2} \mathrm{O}_{5}$, mycorrhizal colonization did not increase soybean productivity, regardless of stimulation by formononetin (Figure 2 and 3). The absence of effect $(P>0.05)$ of formononetin on soybean productivity with no addition of $\mathrm{P}_{2} \mathrm{O}_{5}$ indicates that application of this isoflavone alone is not sufficient to stimulate mycorrhization to the point of meeting soybean $\mathrm{P}$ demand. However, at $60 \mathrm{~kg} \mathrm{ha}^{-1} \mathrm{P}_{2} \mathrm{O}_{5}$, for 2010/11, mycorrhization stimulated by formononetin increased soybean productivity from 2100 to 2500 $\mathrm{kg} \mathrm{ha}^{-1}(P<0.05)$, levels similar to those obtained following the application of $120 \mathrm{~kg} \mathrm{ha}{ }^{-1} \mathrm{P}_{2} \mathrm{O}_{5}$
(Figure 3A). This effect was not observed for 2012/13. The discrepancy in the results from both experiments can be probably attributed to differences in the $\mathrm{P}$ levels originally found in the soils from each area. Although the same P levels $(0$, 60 , and $120 \mathrm{~kg} \mathrm{P}_{2} \mathrm{O}_{5} \mathrm{ha}^{-1}$ ) were used in both experiments, according to the recommendations of Novais et al. (1999) they correspond to 0,75, and $150 \%$ of the recommend dose for 2010/11; and 0 , 50 , and $100 \%$ for $2012 / 13$. Therefore, in 2010/11 the intermediate level of $\mathrm{P}$ addition was already close $(75 \%)$ to the recommended dose, while the maximum level of $\mathrm{P}$ applied was excessive $(150 \%)$ for this soil.

These field-based results indicate the potential of formononetin as a technology to sustain soybean productivity while decreasing the costs associated with $\mathrm{P}$ fertilization. Because formononetin can be applied directly to the seed, labor costs may be reduced.

There are also environmental gains to be considered because $\mathrm{P}$ fertilizers used in agriculture originate from non-renewable natural sources. There is an increasing demand for the use of these resources, with a consequent increase in the costs of the agriculture production chain. The use of formononetin may be a sustainable alternative for reducing the use of $\mathrm{P}$ fertilizers. However, further studies elucidating the factors that control the efficiency of formononetin in field conditions are still necessary to increase the reliability of this technology under varying edaphoclimatic conditions. 
Table 2. Average values of $\mathrm{N}$ and $\mathrm{P}$ concentrations and contents in the shoots of soybean cv. Favorita RR at flowering in two crop seasons with different phosphorus levels and formononetin doses.

\begin{tabular}{|c|c|c|c|c|c|c|c|c|}
\hline \multirow{4}{*}{$\begin{array}{c}\text { Phosphorus } \\
\text { Levels } \\
\left(\mathrm{kg} \mathrm{ha}^{-1}\right)\end{array}$} & \multicolumn{8}{|c|}{ Concentrations of $\mathrm{N}$ and $\mathrm{P}$ in the shoots } \\
\hline & \multicolumn{8}{|c|}{ Formononetin doses $\mathrm{g} \mathrm{ha}^{-1}$} \\
\hline & \multicolumn{4}{|c|}{$2010 / 11$} & & \multicolumn{3}{|c|}{$2012 / 13$} \\
\hline & 0 & 25 & 50 & 100 & 0 & 25 & 50 & 100 \\
\hline \multicolumn{9}{|l|}{$\mathrm{Ng} / \mathrm{kg}$} \\
\hline 0 & $22.2 \mathrm{aA}$ & $22.0 \mathrm{aA}$ & $21.8 \mathrm{aA}$ & $20.8 \mathrm{aA}$ & $23.7 \mathrm{aA}$ & $23.7 \mathrm{aA}$ & $19.7 \mathrm{aA}$ & $24.0 \mathrm{aA}$ \\
\hline 60 & $21.2 \mathrm{aA}$ & $23.2 \mathrm{aA}$ & $21.8 \mathrm{aA}$ & $21.6 \mathrm{aA}$ & $20.7 \mathrm{aA}$ & $27.7 \mathrm{aA}$ & $23.0 \mathrm{aA}$ & $26.2 \mathrm{aA}$ \\
\hline 120 & $20.8 \mathrm{aA}$ & $18.2 \mathrm{aA}$ & $23.2 \mathrm{aA}$ & $20.0 \mathrm{aA}$ & $21.5 \mathrm{aA}$ & $24.0 \mathrm{aA}$ & $25.7 \mathrm{aA}$ & $20.2 \mathrm{aA}$ \\
\hline \multicolumn{9}{|l|}{$\mathrm{P} \mathrm{g} / \mathrm{kg}$} \\
\hline 0 & $1.00 \mathrm{aA}$ & $1.00 \mathrm{aA}$ & $1.20 \mathrm{aA}$ & $1.00 \mathrm{aA}$ & $1.10 \mathrm{aA}$ & $1.10 \mathrm{aA}$ & $1.20 \mathrm{aA}$ & $1.20 \mathrm{aA}$ \\
\hline 60 & $1.00 \mathrm{aA}$ & $1.00 \mathrm{aA}$ & $1.20 \mathrm{aA}$ & $1.00 \mathrm{aA}$ & $1.10 \mathrm{aA}$ & $1.30 \mathrm{aA}$ & $1.30 \mathrm{aA}$ & $1.20 \mathrm{aA}$ \\
\hline 120 & $1.00 \mathrm{aA}$ & $1.20 \mathrm{aA}$ & $1.20 \mathrm{aA}$ & $1.00 \mathrm{aA}$ & $1.20 \mathrm{aA}$ & $1.20 \mathrm{aA}$ & $1.20 \mathrm{aA}$ & $1.30 \mathrm{aA}$ \\
\hline & \multicolumn{8}{|c|}{ Contents of $\mathrm{N}$ and $\mathrm{P}$ in the shoots } \\
\hline \multicolumn{9}{|l|}{$\mathrm{N}$ mg/plant } \\
\hline 0 & $178.47 \mathrm{aA}$ & $254.01 \mathrm{aA}$ & $192.46 \mathrm{aA}$ & $183.60 \mathrm{aA}$ & $225.72 \mathrm{aA}$ & $224.35 \mathrm{bA}$ & $205.84 \mathrm{cA}$ & $266.44 \mathrm{bA}$ \\
\hline 60 & $225.26 \mathrm{aA}$ & $229.39 \mathrm{aA}$ & $264.12 \mathrm{aA}$ & $260.51 \mathrm{aA}$ & $218.88 \mathrm{aB}$ & $303.19 \mathrm{aA}$ & $268.29 \mathrm{bB}$ & $323.23 \mathrm{aA}$ \\
\hline 120 & $216.45 \mathrm{aA}$ & $209.83 \mathrm{aA}$ & $253.25 \mathrm{aA}$ & $229.13 \mathrm{aA}$ & $266.01 \mathrm{aA}$ & $308.18 \mathrm{aA}$ & $321.73 \mathrm{aA}$ & $267.89 \mathrm{bA}$ \\
\hline \multicolumn{9}{|l|}{ P mg/plant } \\
\hline 0 & $9.87 \mathrm{aA}$ & $12.00 \mathrm{aA}$ & $10.72 \mathrm{aA}$ & $10.62 \mathrm{aA}$ & $10.54 \mathrm{bB}$ & $10.03 \mathrm{bB}$ & $12.19 \mathrm{bA}$ & $13.93 \mathrm{bA}$ \\
\hline 60 & $11.27 \mathrm{aA}$ & $12.11 \mathrm{aA}$ & $14.78 \mathrm{aA}$ & $14.35 \mathrm{aA}$ & $11.59 \mathrm{bB}$ & $14.38 \mathrm{aA}$ & $15.55 \mathrm{aA}$ & $14.52 \mathrm{bA}$ \\
\hline 120 & $11.70 \mathrm{aA}$ & $15.46 \mathrm{aA}$ & $14.41 \mathrm{aA}$ & $12.50 \mathrm{aA}$ & $15.09 \mathrm{aA}$ & $15.59 \mathrm{aA}$ & $14.72 \mathrm{aA}$ & $16.62 \mathrm{aA}$ \\
\hline
\end{tabular}

lower case letters indicate comparisons among different $\mathrm{P}_{2} \mathrm{O}_{5}$ addition levels within the same agricultural year. 

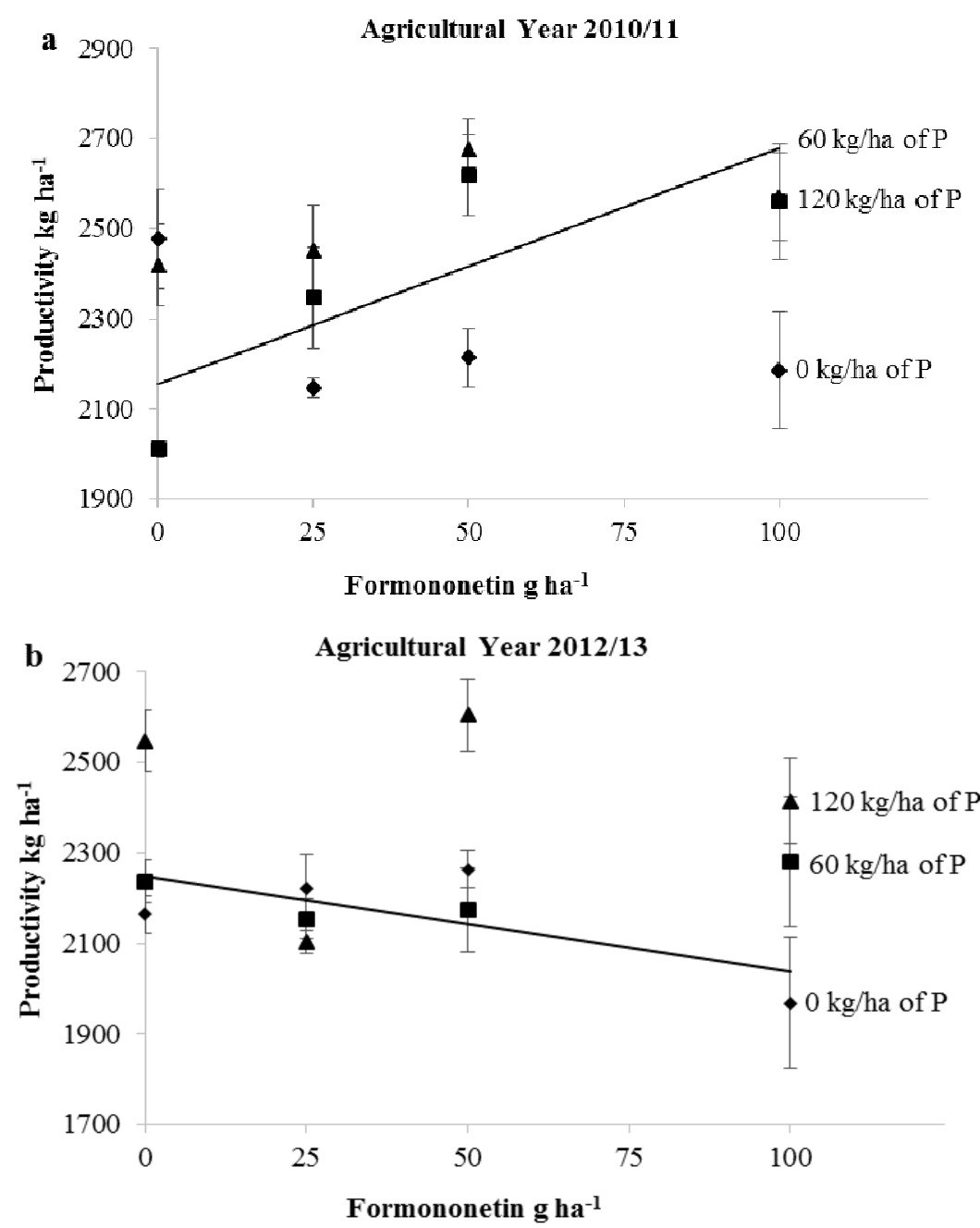

Figure 3. Productivity of soybean after treatment with different doses of formononetin and different levels $\mathrm{P}$ for the agricultural years (A) 2010/11 and (B) 2012/13. * Significant at $P<0.05$ and ns not significant according to the $\mathrm{F}$ test. (A) $\mathrm{y}_{0}=-2.1619 \mathrm{x}+2350.8 \mathrm{R}^{2}=0.38^{\mathrm{ns}} ; \mathrm{y}_{60}=5.2043 \mathrm{x}+2156 \mathrm{R}^{2}$ $=0.65^{*} ; \mathrm{y}_{120}=1.7282 \mathrm{x}+2452.8 \mathrm{R}^{2}=0.40^{\text {ns }}$ and $(\mathrm{B}) \mathrm{y}_{0}=-2.096 \mathrm{x}+2246.3 \mathrm{R}^{2}=0.47^{*} ; \mathrm{y}_{60}=0.6572 \mathrm{x}$ $+2182.7 \mathrm{R}^{2}=0.24^{\mathrm{ns}} ; \mathrm{y}_{120}=0.2163 \mathrm{x}+2407.4 \mathrm{R}^{2}=0.00^{\mathrm{ns}}$.

\section{CONCLUSIONS}

Formononetin stimulates mycorrhization at lower levels of $\mathrm{P}$ fertilization, but it does not increase soybean productivity without $\mathrm{P}$ addition.

When combined with intermediate levels of $\mathrm{P}$ addition, formononetin increased productivity in 2010/11 to levels equivalent to those obtained with the use of the maximum level of $\mathrm{P}_{2} \mathrm{O}_{5}$ for soybean cultivation utilized in this study.

High doses of formononetin (50 and $100 \mathrm{~g}$ $\mathrm{ha}^{-1}$ ) associated with $\mathrm{P}$ addition generally stimulated plant growth in 2012/13, but did not increase productivity in this agricultural year.

\section{ACKNOWLEDGMENTS}

We thank the National Council for Scientific and Technological Development (CNPq) Process 559120/2009-5 and the Ministry of Science and Technology, for financial support and the Coordination for the Improvement of Higher Education Personnel (CAPES) by scholarship. 
RESUMO: Os Fungos micorrízicos arbusculares desempenham papel importante no fornecimento de nutrientes para as plantas, especialmente P. No entanto, a disponibilidade de inoculantes com esses fungos, para o uso em larga escala na agricultura é ainda limitada, porque estes organismos são simbiontes obrigatórios. O uso de estimulantes simbióticos, como os flavonóides, podem ser uma alternativa para melhorar os efeitos benéficos da micorrrização na nutrição das plantas. O objetivo neste estudo foi avaliar o efeito do isoflavonóide bioestimulante formononetina (7-hidroxi, 4'-metoxi isoflavona) em combinação com três níveis de adubação fosfatada sobre a colonização micorrízica, a nodulação e a produtividade da soja, em condições de campo. Um esquema fatorial 3 x 4 (níveis de P: 0,60 e $120 \mathrm{~kg} \mathrm{ha}^{-1}$ de $\mathrm{P}_{2} \mathrm{O}_{5}$ e doses de formononetina: $0,25,50 \mathrm{e} 100 \mathrm{~g} \mathrm{ha}^{-1}$ ) foi utilizado, com cinco repetições. Os seguintes parâmetros foram quantificados em plena floração: altura da planta, matéria seca da parte aérea, número e matéria seca de nódulos, colonização micorrízica, e concentrações de $\mathrm{N}$ e $\mathrm{P}$ na parte aérea das plantas. A produtividade também foi avaliada no final do ciclo da cultura. A Formononetina estimulou a colonização micorrízica em níveis mais baixos de $\mathrm{P}(0$ e $60 \mathrm{~kg}$ ha ${ }^{1}$ ), com aumentos de 56-64\%. Quando aplicado com $60 \mathrm{~kg} \mathrm{ha}^{-1}$ de $\mathrm{P}_{2} \mathrm{O}_{5}$, a formononetina aumentou a produtividade da soja, alcançando valores semelhantes aos observados quando foi aplicado $120 \mathrm{~kg} \mathrm{ha}^{-1}$ de $\mathrm{P}_{2} \mathrm{O}_{5}$. Em doses acima de $50 \mathrm{~g}$ ha 1, a formononetina aplicada na semente pode reduzir a necessidade de fertilização fosfatada em $50 \%$.

PALAVRAS-CHAVE: Micorriza arbuscular. Glycine max. Adubação fosfatada. Isoflavónoide. Fixação Biológica de $\mathrm{N}_{2}$.

\section{REFERENCES}

ANTUNES, P. M.; RAJCAN I.; GOSS, M. J. Specific flavonoids as interconnecting signals in the tripartite symbiosis formed by arbuscular mycorrhizal fungi, Bradyrhizobium japonicum (Kirchner) Jordan and soybean (Glycine $\max$ (L.) Merr.). Soil Biology and Biochemistry, Oxford, v. 38, n. 3, p. 533-543, 2006.

http://dx.doi.org/10.1016/j.soilbio.2005.06.008

CONAB - National Food Supply Company. Follow up of the Brazilian grains crops. Brasília, v. 1, n. 2, 2013. Available at: <http://www.conab.gov.br>. Access in January 25, 2014.

CORDEIRO, M. A. S.; FERREIRA, D. A. F.; PAULINO, H. B. SOUZA, C. R. F.; SIQUEIRA, J. O.; CARNEIRO, M. A. C. Mycorrhization stimulant based in formononetin associated to fungicide and doses of phosphorus in soybean in the cerrado. Bioscience Journal, v. 31, n. 4, p. 1062-1070, 2015. http://dx.doi.org/10.14393/BJ-v31n4a2015-26185

DAVIES, JR. F. T.; CALDERÓN, C. M.; HUAMAN, Z., GÓMEZ, R. Influence of a flavonoid (formononetin) on mycorrhizal activity and potato crop productivity in the highlands of Peru. Scientia Horticulturae, Amsterdam, v. 106, n. 3, p. 318-329, 2005a.

DAVIES JR, F. T.; CALDERÓN, C.M.; HUAMAN, Z. Influence of Arbuscular Mycorrhizae Indigenous to Peru and a Flavonoid on Growth, Yield, and Leaf Elemental Concentration of 'Yungay' Potatoes. HortScience, Alexandria, v. 40, n. 2, 381-385, april. 2005b. http://dx.doi.org/10.1016/j.scienta.2005.04.013

FARIAS, J. R. B.; NEPOMUCENO, A.L.; NEUMAIER, N. Ecofisiologia da soja. Embrapa Soja, Londrina, (Circular técnica, 48), 2007.

FERREIRA, D. F. Sisvar a computer statistical analysis system. Ciência Agrotecnologia, Lavras, v. 35, n. 6, p. 1039-1042, 2011.

FLORENTINO, L. A.; MOREIRA, F. M. S. Symbiotic and phenotypic characteristics of Azorhizobium doebereinerae, microsymbiot of Sesbania virgata. Revista Árvore. Viçosa, v. 33, n. 2, p. 215-226, 2009.

GERDEMANN, J. W.; NICOLSON, T. H. Spores of mycorrhizal endogone species extracted from soil by wet sieving and decanting. Transactions of the British Mycological Society, London, v. 46, n. 2, p. 235-244, 1963. http://dx.doi.org/10.1016/S0007-1536(63)80079-0 
GIOVANNETTI, M.; MOSSE, B. An evaluation of techniques for measuring vesicular arbuscular mycorrhizal infection in roots. New Phytologist, London, v. 84, n.3, p. 489-500, mar. 1980.

http://dx.doi.org/10.1111/j.1469-8137.1980.tb04556.x

HOAGLAND, D.; ARNON, D. I. The water culture method for growing plants without soil. University of California, Berkeley, CA, USA (AES Circular, 347). 1950.

KÖPPEN, W. Das geographische System der Klimate. - KÖPPEN, W., R. GEIGER (Eds.): Handbuch der Klimatologie. - Gebrüder Bornträger, Berlin, 1, 1-44, 1936.

KOSKE, R. E.; GEMMA, J. N. A modified procedure for staining roots to detect VA mycorrhizas.

Mycological Research, Cambridge, v. 92, n. 4, p. 486-488, 1989. http://dx.doi.org/10.1016/S0953-

7562(89)80195-9

KOSSLAK, R. M.; BOOKLAND, R.; BARKEI, J.; PAAREN, H. E.; APPELBAUM, E. R. Induction of Bradyrhizobium japonicum common nod genes by isoflavonoids isolated from Glycine max. Proceedings of the National Academy of Sciences of the United States of America, Washington, v. 84, n. 21, p. 7428-7432, 1987.

MALAVOLTA, E.; VITTI, G. C.; OLIVEIRA, S. A. Avaliação do estado nutricional das plantas: princípios e aplicações. 2. ed. Piracicaba: Potafos, 1997. 319p.

MALAVOLTA, E. Manual de nutrição mineral de plantas, first ed. São Paulo: Agronômica Ceres, 2006. $638 \mathrm{p}$.

MOREIRA, F. M. S.; SIQUEIRA, J. O. Microbiologia e bioquímica do solo. 2. ed. Lavras: UFLA, 2006. 729p. http://dx.doi.org/10.1007/s00374-010-0477-5

MOREIRA, F. M. S.; CARVALHO, T. S.; SIQUEIRA, J. O. Effect of fertilizers, lime, and inoculation with rhizobia and mycorrhizal fungi on the growth of four leguminous tree species in a low-fertility soil. Biology and Fertility of Soils, v. 46, n. 8, p. 771-779, 2010.

NAIR, M. G.; SAFIR, G. R.; SIQUEIRA, J. O. Isolation and identification of vesicular-arbuscular mycorrhiza stimulatory compounds from clover (Trifolium repens) roots. Applied and Environmental Microbiology. Washington, v. 57, n. 2, p. 434-439, 1991.

NOVAIS, R. F. Soja, in: Ribeiro, A.C., Guimarães, P.T., Alvarez, V.H. (eds.), Recomendações para o Uso de Corretivos e Fertilizantes em Minas Gerais - 5a Aproximação. SBCS, Viçosa-MG, Brasil, p. 323-324. 1999. http://dx.doi.org/10.1590/S0100-204X2009000500009

NOVAIS, C. B.; SIQUEIRA, J. O. Formononetin application on colonization and sporulation of arbuscular mycorrhizal fungi in Brachiaria. Pesquisa Agropecuária Brasileira, Brasília, v. 44, n. 5, p. 496-502, 2009.

OZAN, A.; SAFIR, G. R.; NAIR, M. G. Persistence of isoflavones formononetin and biochanin A in soil and their effects on soil microbe population. Journal of Chemical Ecology, New York, v. 23, n. 2, p. 247-258, 1997. http://dx.doi.org/10.1023/B:JOEC.0000006357.18358.14

PARNISKE, M. Arbuscular mycorrhiza: The mother of plant root endosymbioses. Nature Reviews Microbiology, England, v. 6, n. 10, 763-775, 2008. http://dx.doi.org/10.1038/nrmicro1987

SILVA-JÚNIOR J. P.; SIQUEIRA, J. O. Soil-applied synthetic formononetin stimulates arbuscular mycorrhizal formation in corn and soybean. Revista Brasileira de Fisiologia Vegetal, Londrina, v. 9, n. 1, p. 33-39, 1997. 
SILVA-JÚNIOR, J. P.; SIQUEIRA, J. O. Mycorrhizal colonization and growth of soybean influenced by different fungal species and application of the isoflavonoid formononetin. Pesquisa Agropecuária Brasileira, Brasília v. 33, n. 6, p. 953-959, 1998.

SIQUEIRA, J. O.; SAFIR, G. R.; NAIR, M. G. Stimulation of vesicular-arbuscular mycorrhiza formation and growth of white clover by flavonoid compounds. New Phytologist, London, v. 118, n. 1, p. 87-93, 1991a. http://dx.doi.org/10.1111/j.1469-8137.1991.tb00568.x

SIQUEIRA, J. O.; SAFIR, G. R.; NAIR, M. G. VA-mycorrhizae and mycorrhiza stimulating isoflavonoid compounds reduce plant herbicide injury. Plant and Soil, Netherlands, v. 134, n. 2, p. 233-242, 1991b. http://dx.doi.org/10.1007/BF00012041

SMITH, S. E.; READ, D. M. Mycorrhizal Symbiosis. 2. ed. London: Academic Press, 1997. 605 p.

STÜRMER, S. L.; SIQUEIRA, J. O. Fungos micorrízicos. In: MOREIRA, F. M. S.; CARES, J. E.; ZANETTI, R.; STÜRMER, S. L. (Ed.). O ecossistema solo: componentes, relações ecológicas e efeitos na produção vegetal. Lavras: UFLA, 2013. p. 291-310.

WANG, X.; PAN, Q.; CHEN, F.; YAN, X.; LIAO, H. Effects of co-inoculation with arbuscular mycorrhizal fungi and rhizobia on soybean growth as related to root architecture and availability of $\mathrm{N}$ and $\mathrm{P}$. Mycorrhiza, v. 21, n. 3, p. 173-181, 2011. http://dx.doi.org/10.1007/s00572-010-0319-1

WOOMER, A. N.; SINGLETON, P. W.; BOHLOOL, B. B. Ecological indicators of native rhizobia in tropical soils. Applied and environmental microbiology, Washington, v. 54, n. 5, p. 1112-1116, 1988.

YAMADA, T.; ABDALLA, S. R. S. Fósforo na Agricultura Brasileira. Piracicaba: Potafos; 2004. 